NATIONAL LABORATORY

MANAGED BY UT-BATTELLE

FOR THE DEPARTMENT OF ENERGY

\section{Hydrogen-or-Fossil-Combustion Nuclear Combined-Cycle Systems for Base- and Peak-Load Electricity Production}

C. W. Forsberg and James C. Conklin Oak Ridge National Laboratory

September 2007

\section{UT-BATTELLE}


This report was prepared as an account of work sponsored by an agency of the United States Government. Neither the United States government nor any agency thereof, nor any of their employees, makes any warranty, express or implied, or assumes any legal liability or responsibility for the accuracy, completeness, or usefulness of any information, apparatus, product, or process disclosed, or represents that its use would not infringe privately owned rights. Reference herein to any specific commercial product, process, or service by trade name, trademark, manufacturer, or otherwise, does not necessarily constitute or imply its endorsement, recommendation, or favoring by the United States Government or any agency thereof. The views and opinions of authors expressed herein do not necessarily state or reflect those of the United States Government or any agency thereof. 


\title{
Hydrogen-or-Fossil-Combustion Nuclear Combined-Cycle Systems for Base- and Peak-Load Electricity Production
}

\author{
C. W. Forsberg* \\ Oak Ridge National Laboratory \\ Oak Ridge, Tennessee \\ J. C. Conklin** \\ Oak Ridge National Laboratory \\ Oak Ridge, Tennessee
}

Date Published: September 2007

\author{
Prepared by \\ OAK RIDGE NATIONAL LABORATORY \\ Oak Ridge, Tennessee 37831-6285 \\ managed by \\ UT-BATTELLE, LLC \\ for the \\ U.S. DEPARTMENT OF ENERGY \\ under contract DE-AC05-00OR22725
}

*P.O. Box 2008, Oak Ridge, TN 37831-6165; Tel: (865) 574-6783; Email: forsbergcw@,ornl.gov
**P.O. Box 2008, Oak Ridge, TN 37831-6472; Tel: (865) 946-1340; Email: $\underline{\text { conklinjc@ornl.gov }}$ 



\section{CONTENTS}

LIST OF FIGURES

Page

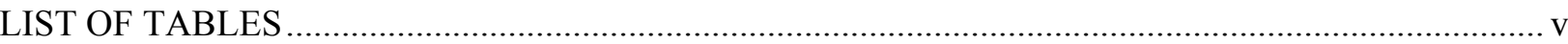

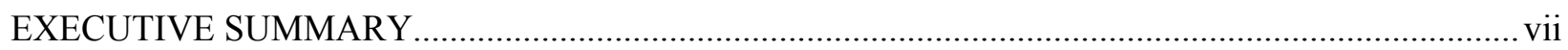

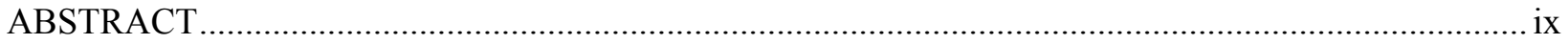

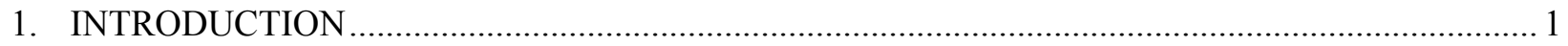

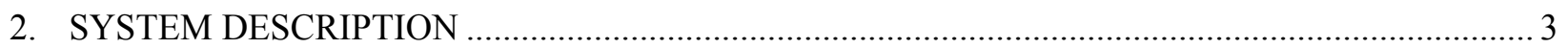

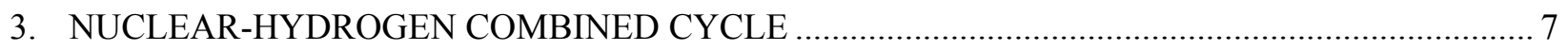

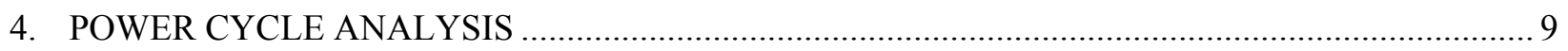

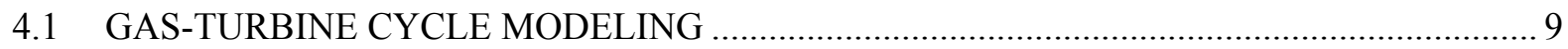

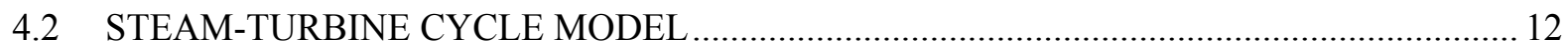

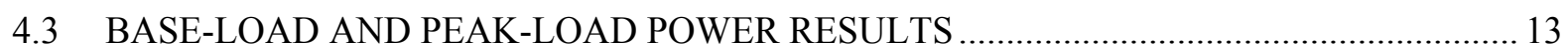

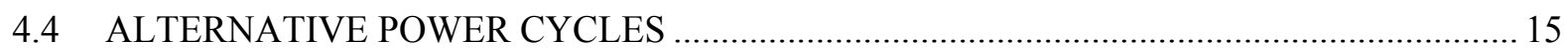

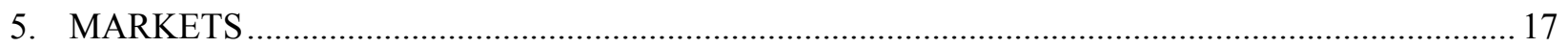

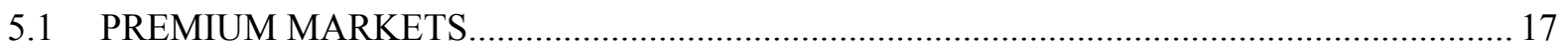

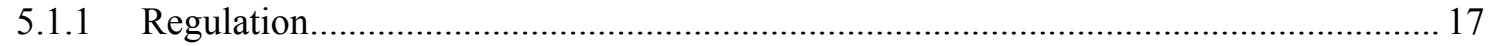

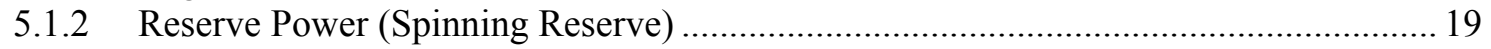

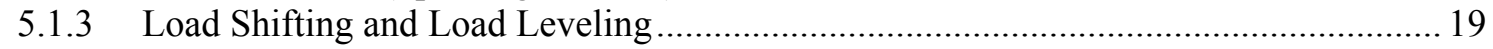

5.2 SMALL-GRID MARKETS (INCLUDING DEVELOPING COUNTRIES) ......................... 21

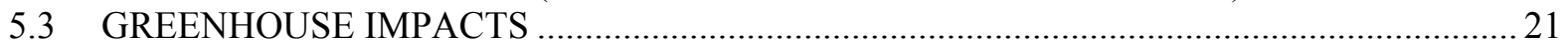

6. REACTOR AND INTERMEDIATE HEAT-TRANSPORT LOOP OPTIONS …............................ 23

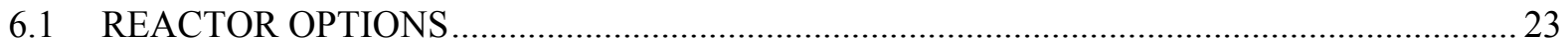

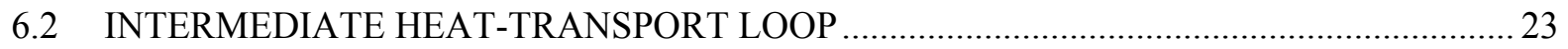

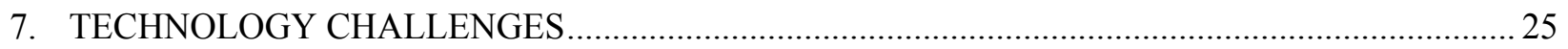

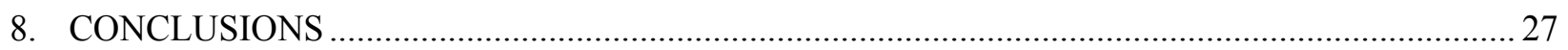

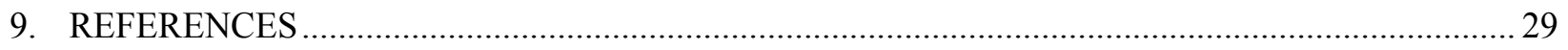




\section{LIST OF FIGURES}

Figure $\quad$ Page

$1 \quad$ Nuclear-combustion combined-cycle electric plant ................................................................... 3

2 Gas-turbine thermal efficiency vs specific power for pressure ratios from 2 to 30

(excludes heat recovery steam system and steam turbine) ....................................................... 10

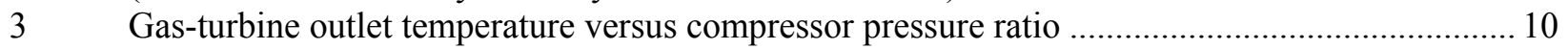

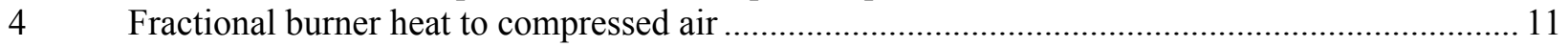

5 A typical electric-power demand load on the ERCOT (Electric Reliability Council of Texas)

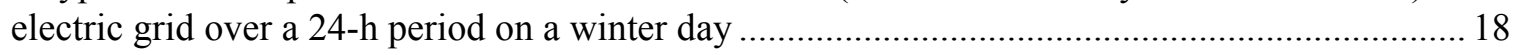

\section{LIST OF TABLES}

Table

Page

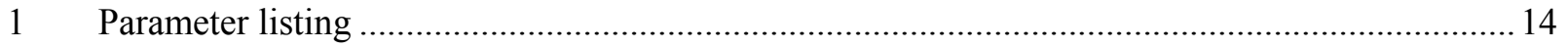

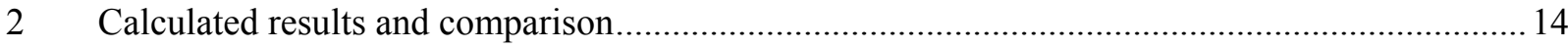

3 Premium power-grid electrical markets in the United States................................................ 17

42004 Electricity prices versus the number of hours for different electrical grids .......................20 


\section{EXECUTIVE SUMMARY}

A combined-cycle power plant is described that uses (1) heat from a high-temperature nuclear reactor to meet base-load electrical demands and (2) heat from the same high-temperature reactor and burning natural gas, jet fuel, or hydrogen to meet peak-load electrical demands. For base-load electricity production, fresh air is compressed; then flows through a heat exchanger, where it is heated to between 700 and $900^{\circ} \mathrm{C}$ by heat provided by a high-temperature nuclear reactor via an intermediate heat-transport loop; and finally exits through a high-temperature gas turbine to produce electricity. The hot exhaust from the Brayton-cycle gas turbine is then fed to a heat recovery steam generator that provides steam to a steam turbine for added electrical power production.

To meet peak electricity demand, the air is first compressed and then heated with the heat from a hightemperature reactor. Natural gas, jet fuel, or hydrogen is then injected into the hot air in a combustion chamber, combusts, and heats the air to $1300^{\circ} \mathrm{C}$ - the operating conditions for a standard natural-gas-fired combined-cycle plant. The hot gas then flows through a gas turbine and a heat recovery steam generator before being sent to the exhaust stack. The higher temperatures increase the plant efficiency and power output. If hydrogen is used, it can be produced at night using energy from the nuclear reactor and stored until needed. With hydrogen serving as the auxiliary fuel for peak power production, the electricity output to the electric grid can vary from zero (i.e., when hydrogen is being produced) to the maximum peak power while the nuclear reactor operates at constant load. Because nuclear heat raises air temperatures above the auto-ignition temperatures of the various fuels and powers the air compressor, the power output can be varied rapidly (compared with the capabilities of fossil-fired turbines) to meet spinning reserve requirements and stabilize the electric grid.

This combined cycle uses the unique characteristics of high-temperature reactors $\left(T>700^{\circ} \mathrm{C}\right)$ to produce electricity for premium electric markets whose demands can not be met by other types of nuclear reactors. It may also make the use of nuclear reactors economically feasible in smaller electrical grids, such as those found in many developing countries. The ability to rapidly vary power output can be used to stabilize electric grid performance - a particularly important need in small electrical grids. 


\begin{abstract}
An air combined-cycle power plant is described that uses (1) heat from a high-temperature nuclear reactor to meet base-load electrical demands and (2) heat from the same high-temperature reactor and the combustion of natural gas, jet fuel, or hydrogen to meet peak-load electrical demands. By using lowercost nuclear heat from a high-temperature reactor, a combined-cycle plant can reduce the cost of peak power. The heat from the reactor raises the incoming air temperature above the auto-ignition temperature of the hydrogen or fossil fuel. This eliminates the need to match fuel-to-air ratios to assure stable and complete combustion. As a consequence, the combined-cycle system can vary electric output much more rapidly than traditional utility natural-gas-fired combined-cycle plants, thus enabling the system to be used to meet electric-grid spinning reserve requirements and help stabilize the electric grid. These same capabilities may also allow high-temperature reactors to provide economic power to small electrical grids (such as those found in many developing countries) where grid stability is a major constraint to the use of nuclear power. The option exists to produce hydrogen at night using energy from the nuclear reactor and storing it until it is needed for peak power production. With hydrogen as the auxiliary fuel for peak power production, the electricity output to the electric grid can vary from zero (i.e., when hydrogen is being produced) to the maximum peak power while the nuclear reactor operates at constant load. This system provides peak power without greenhouse gas emissions.
\end{abstract}




\section{INTRODUCTION}

A new type of nuclear combustion combined-cycle (NCCC) power plant is proposed that uses hightemperature nuclear heat for base-load electricity production and high-temperature nuclear heat supplemented with the combustion of fossil fuels or hydrogen for peak-load electricity production. It is a unique application for nuclear energy in that it (1) may enable nuclear energy to meet premium-price electricity market requirements in advanced industrialized countries and (2) may match the technical and economic requirements for a power plant connected to a small electrical grid such as those found in many developing countries. The concept, which has been under investigation for about a year, is only in its early stages of development.

This report provides a system description, an initial power cycle analysis, an analysis of markets, and high-temperature reactor options for an NCCC plant, as well as identification of the technical challenges. Also discussed is the option of using hydrogen as a fuel. The hydrogen used would be produced by the reactor during times of low power demand. 


\section{SYSTEM DESCRIPTION}

An NCCC power plant is proposed (Fig. 1) that uses heat from a high-temperature nuclear reactor and fuel (natural gas, jet fuel, or hydrogen) to meet base-load and peak electrical demands. The design for this type of plant is based on preliminary work conducted on a nuclear-natural gas combined-cycle system $^{1}$ and studies of other systems used to meet peak power demand. ${ }^{2}$ For base-load electricity production, air is first compressed; then flows through a heat exchanger, where it is heated to between 700 and $900^{\circ} \mathrm{C}$; and exits finally through a high-temperature gas turbine to produce electricity. The heat, via an intermediate heat-transport loop, ${ }^{3}$ is provided by a high-temperature reactor. ${ }^{4,5}$ The hot exhaust gases from the Brayton-cycle turbine are then fed to a heat recovery steam generator (HRSG) that provides steam to a steam turbine for added electrical power production.

Gas Turbine Cycle

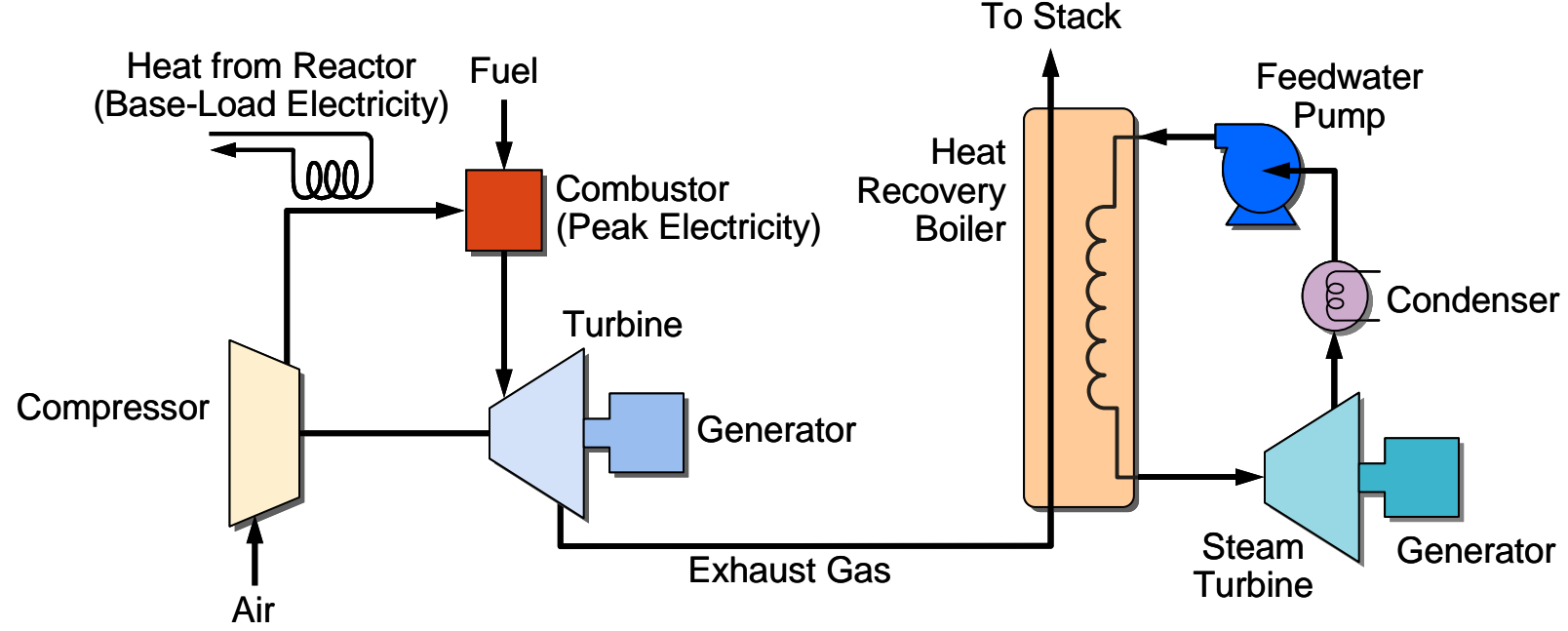

Fig. 1. Nuclear-combustion combined-cycle electric plant. 
To meet peak electrical demand, after the nuclear heating of the compressed air, fuel (natural gas, jet fuel, or hydrogen) is injected into the hot air and burned to increase power levels. This process raises the peak inlet temperatures to both the gas turbine and the steam turbine. In this mode of operation, the peak gasturbine inlet temperature is $\sim 1300^{\circ} \mathrm{C}$-about the same temperature and operating conditions as those of a standard utility natural-gas-fired combined-cycle gas turbine that exhausts its heat to a bottoming Rankine steam cycle.

The nuclear heat raises the temperature of the incoming air above the auto-ignition temperature of the fuel - the temperature at which the fuel will spontaneously burn; thus, the fuel-to-air ratio does not need to be controlled to ensure flame stability and plant operation. The auto-ignition temperatures of natural gas, jet fuel, and hydrogen are 630,240 to 260 , and $570^{\circ} \mathrm{C}$, respectively. Consequently, the combinedcycle plant can operate at any power level between base-load nuclear and the maximum peak power output. In actual practice, however, the temperatures must be somewhat above these temperatures to ensure rapid combustion.

The response time to changes in power demand is much faster in a NCCC plant than in a plant that uses traditional fossil-fueled combustion turbines. As will be discussed in Sect. 5, this capability may enable this technology to meet such utility markets as (1) power regulation and (2) small electrical grids that exist in many developing countries. This capability for rapid changes in power production is a result of the difference in operation of a conventional combustion turbine and a NCCC plant.

- Traditional Brayton power cycle. In a traditional combustion turbine, the fuel-to-air ratio must be controlled to ensure flame stability. To increase the power demand, the airflow (turbine speed) and fuel injection rate are increased simultaneously. As more fuel is added, the extra power is first used to speed up the compressor and increase the airflow. Consequently, there is a significant lag time between the signal for more power and the delivery of more power. This is why the acceleration of a jet aircraft on takeoff is initially slow-the initial increase in turbine power goes into increasing the compressor speed. The same is true of a utility combined-cycle plant.

- Nuclear-heat Brayton power cycle. With nuclear base-load heat, the compressor operates at a constant speed with a constant airflow through the system. When additional electricity is required, fuel is injected into the system. The time between fuel injection into the burner and an increase in power level is determined by the flight time between the fuel injectors and the turbine - a fraction of a second. The air compressor does not change speed or require more energy.

The NCCC plant can use hydrogen as a fuel, an option that would enable this technology to meet variable power demands in a greenhouse-constrained world in which the release of carbon dioxide to the atmosphere is limited. The hydrogen can be made by electrolysis or other methods using nuclear energy from the plant during times of low electrical demand, stored, and then burned at times of peak power demand. With such a system, the nuclear reactor operates at full power at all times (except for maintenance and refueling outages), but the electricity to the electrical grid varies from zero (electricity to hydrogen production) to full power.

The general concept of combining nuclear and a combustion heat source is not new. The Indian Point I pressurized-water reactor in New York had a high-temperature steam cycle in which the reactor provided saturated steam that was then superheated with an oil-fired super heater. The technology of combining nuclear heat sources with Brayton power systems is also not new. The billion-dollar Aircraft Nuclear Propulsion program ${ }^{6}$ of the 1950 s, which had as its goal the development of a nuclear-powered aircraft, developed designs and conducted nonnuclear tests that integrated heat from a secondary liquid heattransport loop into an aircraft jet engine. This program was cancelled because of the weight of the aircraft reactor shielding and the risk of an aircraft crash-factors that do not apply to a stationary power station. 
Initial studies with a simple nuclear natural-gas cycle (Fig. 1) indicate that the turbine conditions will be similar to those of the existing General Electric model MS7001FA gas turbine in terms of gas pressure ratios and peak temperatures. The operating points for base-load electricity production are near the peakefficiency operating conditions for the gas turbine at the lower inlet temperatures, whereas the operating points for peak power production are near the maximum power output condition for the gas turbine at the higher inlet temperatures. A simple combined-cycle system was modeled with a single gas turbine having the same pressure ratio and gas flow rates as the GE turbine and a steam cycle representative of the commercial GE combined-cycle machine. The calculations showed a base-load power output (both gas and steam turbine) of $68.5 \mathrm{MW}(\mathrm{e})$ and a peak-load power output of $276.5 \mathrm{MW}(\mathrm{e})$. For base-load and peak load operations, the reactor provides a constant $175 \mathrm{MW}(\mathrm{t})$ at $800^{\circ} \mathrm{C}$. For peak power production, the natural gas provides an additional $323 \mathrm{MW}(\mathrm{t})$ at a peak gas-turbine inlet temperature of $1300^{\circ} \mathrm{C}$.

The power system size is determined by the available sizes of commercial combined-cycle turbines. The high-temperature reactor may have multiple combined-cycle systems to match reactor output to power conversion system size. The concept of multiple power conversion systems connected to a single reactor is not new. Many Russian reactors have multiple steam systems connected to a single reactor because the reactor sizes were larger than the available steam turbines.

A wide variety of system configurations exist to boost base-load levels to peak power levels, improve efficiency, or increase the nuclear heat fraction when the plant is operating in a peak-power-production mode. These configurations have not yet been analyzed, but are further discussed in Sect. 4.4. Because the base-load plant will operate at a high capacity factor with low-cost nuclear heat, its optimum cycle may be somewhat different from that of traditional natural-gas-fired Brayton power cycles. 


\section{NUCLEAR-HYDROGEN COMBINED CYCLE}

As discussed earlier, the NCCC plant can produce hydrogen using nuclear energy during periods of low electrical demand and then use that hydrogen for peak power production. This option may become particularly attractive if there are constraints on the release of greenhouse gases to the atmosphere from burning fossil fuels. Today's options for producing hydrogen are (1) electrolysis, which produces hydrogen from water; and (2) steam reforming of natural gas or another fossil fuel to produce hydrogen. Use of a fossil fuel as a long-term option for hydrogen production may require carbon dioxide sequestration. $^{7}$ Work is under way to develop lower-cost methods of nuclear hydrogen production including (1) high-temperature electrolysis and hybrid cycles that convert heat, electricity, and water into hydrogen and oxygen; and (2) thermochemical cycles that convert heat and water into hydrogen and oxygen.

The current technology for nuclear hydrogen production is electrolysis, where large-scale electrolyzers have efficiencies of $\sim 73 \%$. This technology is advancing rapidly because potential future markets have led to major increases in research and development programs aimed at driving down capital costs. Recent estimates by manufacturers ${ }^{8}$ indicate that capital costs of $\sim \$ 300 / \mathrm{kW}$ are achievable within the next few years - partly as a result of improved technology and partly because of lower manufacturing costs due to higher production rates. Capital costs are measured $(\$ / \mathrm{kW})$ in terms of the energy value of the hydrogen that is produced. The U.S. Department of Energy ${ }^{9}$ has estimated 2006 electrolyzer capital costs of $\$ 665 / \mathrm{kW}$, with a goal of reducing the capital cost for distributed electrolyzers at hydrogen service stations to $\$ 125 / \mathrm{kW}$ by 2017 . If these cost goals are met, electrolyzer costs will not represent a significant component of the total cost of hydrogen. Most of the cost for hydrogen production will be attributed to electricity.

If electrolysis is used to produce hydrogen, efficiency and capital costs become the critical issues. The potential efficiency gains are reasonably well known because electrolyzer technology is moderately well understood, as are its sources of inefficiencies. Recent studies ${ }^{10}$ of large-scale electrolysis using existing technology and $\$ 0.04 / \mathrm{kW}$-h electricity estimated hydrogen costs at $\$ 2.56 / \mathrm{kg}$, with a cost breakdown as follows: $\$ 2.08 / \mathrm{kg}$ for electricity, $\$ 0.28 / \mathrm{kg}$ for capital recovery, and $\$ 0.20 / \mathrm{kg}$ for operations.

The use of electrolysis introduces two additional economic factors that are not associated with other methods of hydrogen production. First, the output of an electrolyzer can be doubled ${ }^{8}$ with some reduction of efficiency. In effect, the electrolyzer capital costs per unit of output are then reduced by up to a factor of 2. If very low-cost electricity is available at particular times, strong economic incentives will exist to drive the electrolyzers to produce more hydrogen, despite the inefficiencies, and "buy" the hydrogen at a lower cost. Secondly, the power to an electrolyzer can be reduced or increased instantaneously or sequentially with multiple parallel electrolyzers. Hence, the utility can use the electrolyzers for regulation and spinning reserve (see Sect. 5) by dropping or adding electrical load. This capability represents a significant economic benefit ${ }^{11}$ but requires a sophisticated economic analysis to quantify the benefits.

Only one technology presently exists for low-cost storage of hydrogen — storage underground in caverns or geological reservoirs. In the United States, natural gas is stored in $\sim 400$ large facilities, with a total capacity to store one-third of a year's production of natural gas. Use of these facilities represents a lowcost technology, with market prices for storage typically being $10 \%$ of the value of the natural gas. 
Commercial hydrogen storage facilities using geological storage have been built in the United States and Europe. For hydrogen, the capital costs for storage are estimated to be $\$ 0.80-\$ 1.60 / \mathrm{kg}$, which is lower than the total production costs for hydrogen. Although the hydrogen storage technology has been used commercially in several geologies, it has not yet been demonstrated in all geologies that have been used to store natural gas.

Storage economics implies relatively large facilities. Two factors that are almost independent of facility capacity drive the facility size: siting and site development costs (including an understanding of the local geology). Second, gas storage requires compression of the gases, typically to pressures of $\sim 7 \mathrm{MPa}$ ( $\sim 1000$ psi). Gas equipment efficiencies and costs are strongly dependent on the size of the equipment. Low hydrogen storage costs enable the production of hydrogen during times of the day, week, or year with low electricity demand and low electric costs for use for peak electricity at times of high electricity costs. There is the option of seasonal storage of hydrogen for electrical grids where the electrical demand and cost varies significantly depending upon the season. 


\section{POWER CYCLE ANALYSIS}

An analysis of a simplified NCCC power cycle was conducted using the power cycle described earlier as shown in Fig. 1. For the scoping feasibility study presented here, simplified models of the individual components of the gas turbine, HRSG, and Rankine cycle were developed separately and then combined sequentially to determine the combined performance of the thermal power conversion system. Only steady-state conditions were considered, thus energy storage or mass storage dynamic effects were not included.

\subsection{GAS-TURBINE CYCLE MODELING}

In order to calculate the state points of the combined thermal conversion power cycle, the gas turbine portion is developed first. In the first step of the combined-cycle model, heat is added only at the compressor outlet for the simple Brayton cycle. The heat is provided by an intermediate heat-transport loop from the reactor to the NCCC plant with a liquid salt as the heat transfer fluid. To start with the system model, the design parameters of a conventional utility combined-cycle plant were chosen to utilize realistic existing hardware.

The algorithms used for gas turbine performance are those given by Wilson and Korakianitis. ${ }^{12}$ The parameters of most significance in calculating the cycle state points are the compressor pressure ratio, the gas-turbine inlet temperature, the compressor inlet temperature, the compressor and turbine polytropic efficiencies, and total fractional pressure loss. Before determining the performance of the proposed NCCC gas turbine, the performance calculations for a simple gas-turbine cycle for various parameter variations were verified against those presented by Wilson and Korakianitis. ${ }^{12}$

To calculate an initial estimate of gas-turbine performance, the following parameters were chosen. The high-temperature heat was assumed to be provided by an advanced high-temperature reactor (AHTR) with the heat delivered via a liquid-salt intermediate heat-transport loop (Sect. 6). The ambient pressure was set to $100 \mathrm{kPa}$ as appropriate for an open-cycle air machine. The turbomachine polytropic efficiencies were typical of those for the class of machines (large, axial flow) under consideration. The efficiencies, which are functions of the physical size and mass flow rate, can be updated as appropriate in the future.

- Compressor inlet temperature $=10^{\circ} \mathrm{C}$

- $\quad$ AHTR salt temperature $=800^{\circ} \mathrm{C}$

- Combustor outlet temperature $=1300^{\circ} \mathrm{C}$

- Turbine polytropic efficiency $=0.90$

- Compressor polytropic efficiency $=0.85$

- Total fractional pressure $\operatorname{drop}(\Delta \mathrm{P} / \mathrm{P})=0.08$

Because the reactor heat is transferred by a heat exchanger to the compressed air leaving the compressor, an additional parameter of the effectiveness of the salt-to-air heat exchanger was introduced and set to 0.95 . The computed results, as shown in Figs. 2, 3, and 4, depend (some significantly, some not) on the values used for these cycle parameters. The compressor pressure ratio $r_{p}$, defined here as the outlet pressure over the inlet pressure, is a major design parameter for specifying the turbomachinery. Because of the importance of this parameter, a number of important results were calculated as a function of compressor pressure ratio. 


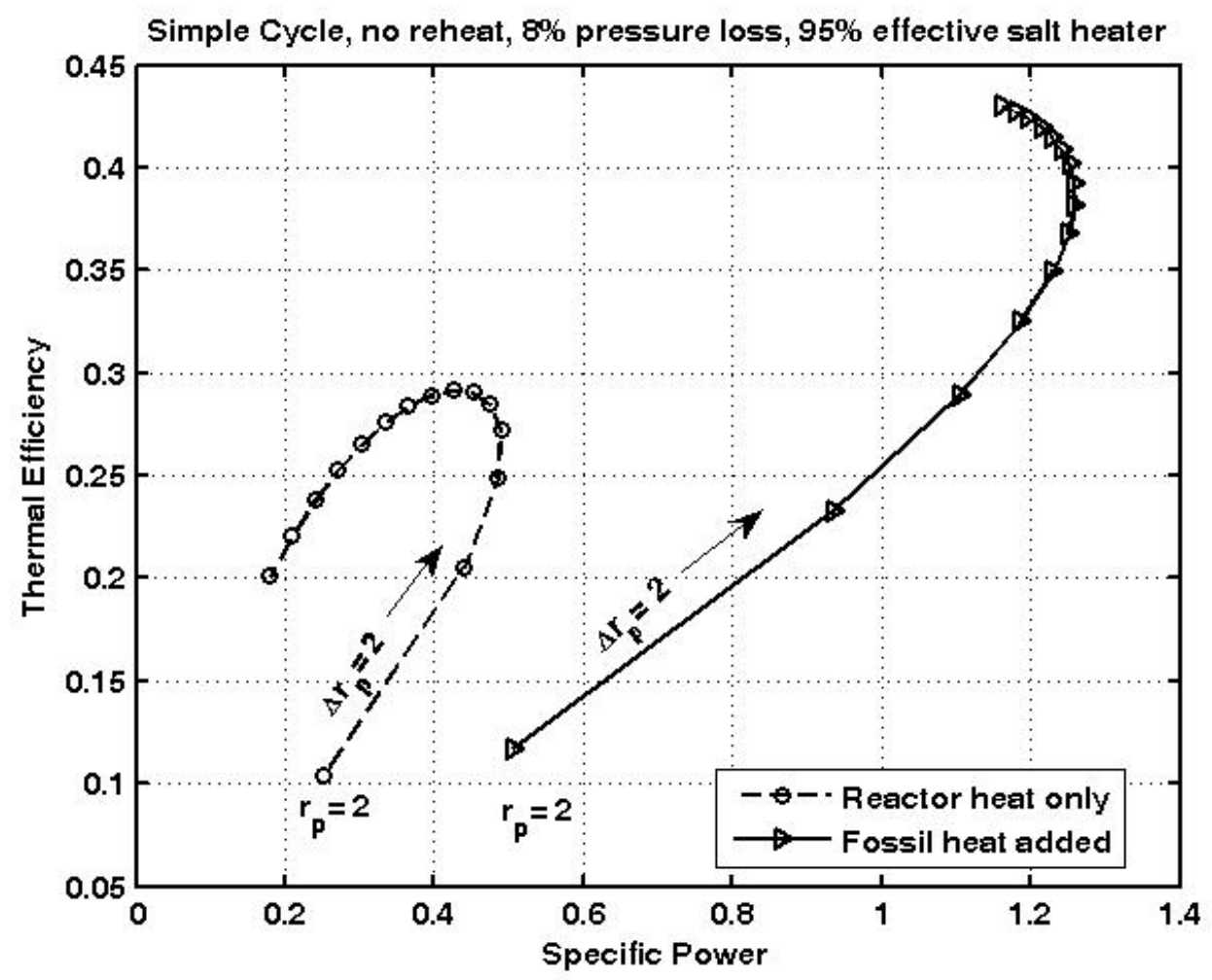

Fig. 2. Gas-turbine thermal efficiency vs specific power for pressure ratios from 2 to 30. (Excludes heat recovery steam system and steam turbine).

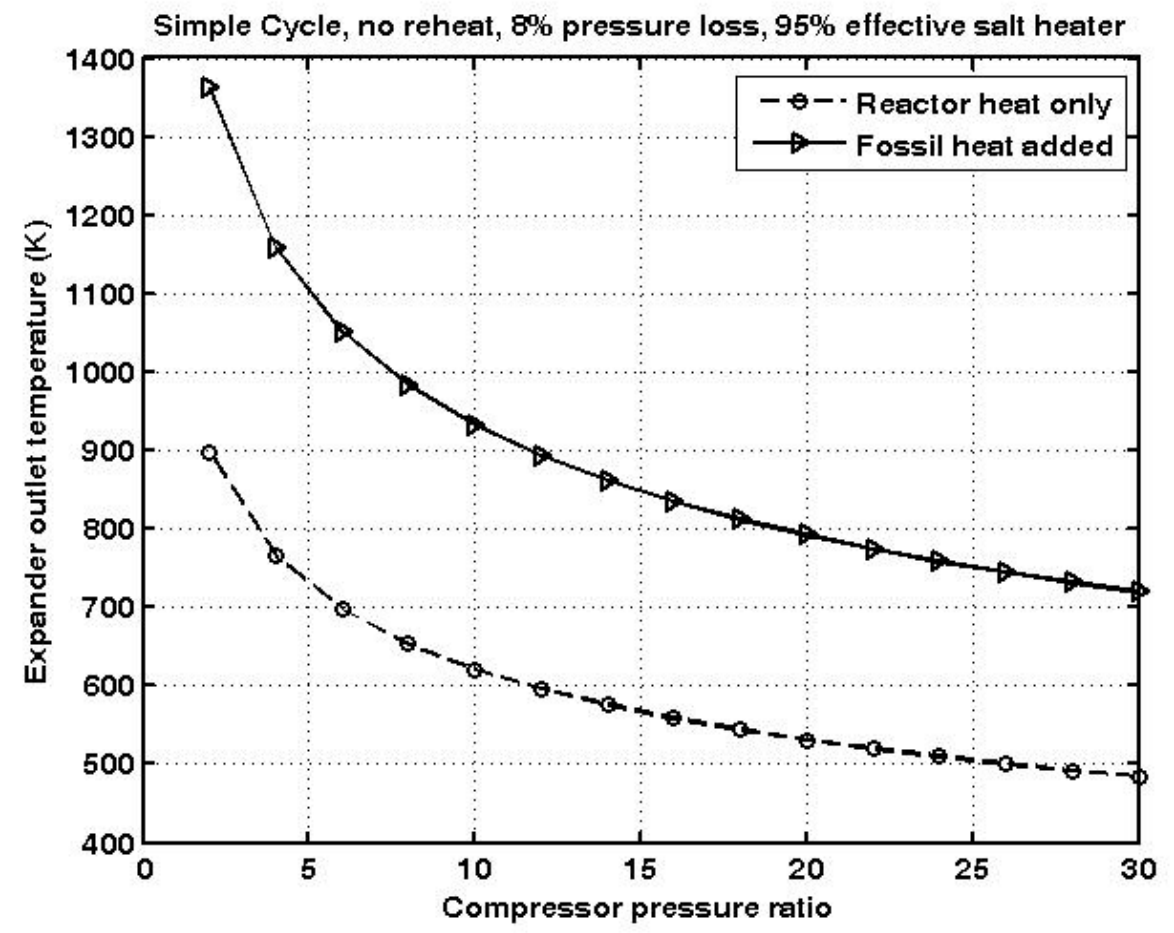

Fig. 3. Gas-turbine outlet temperature versus compressor pressure ratio. 


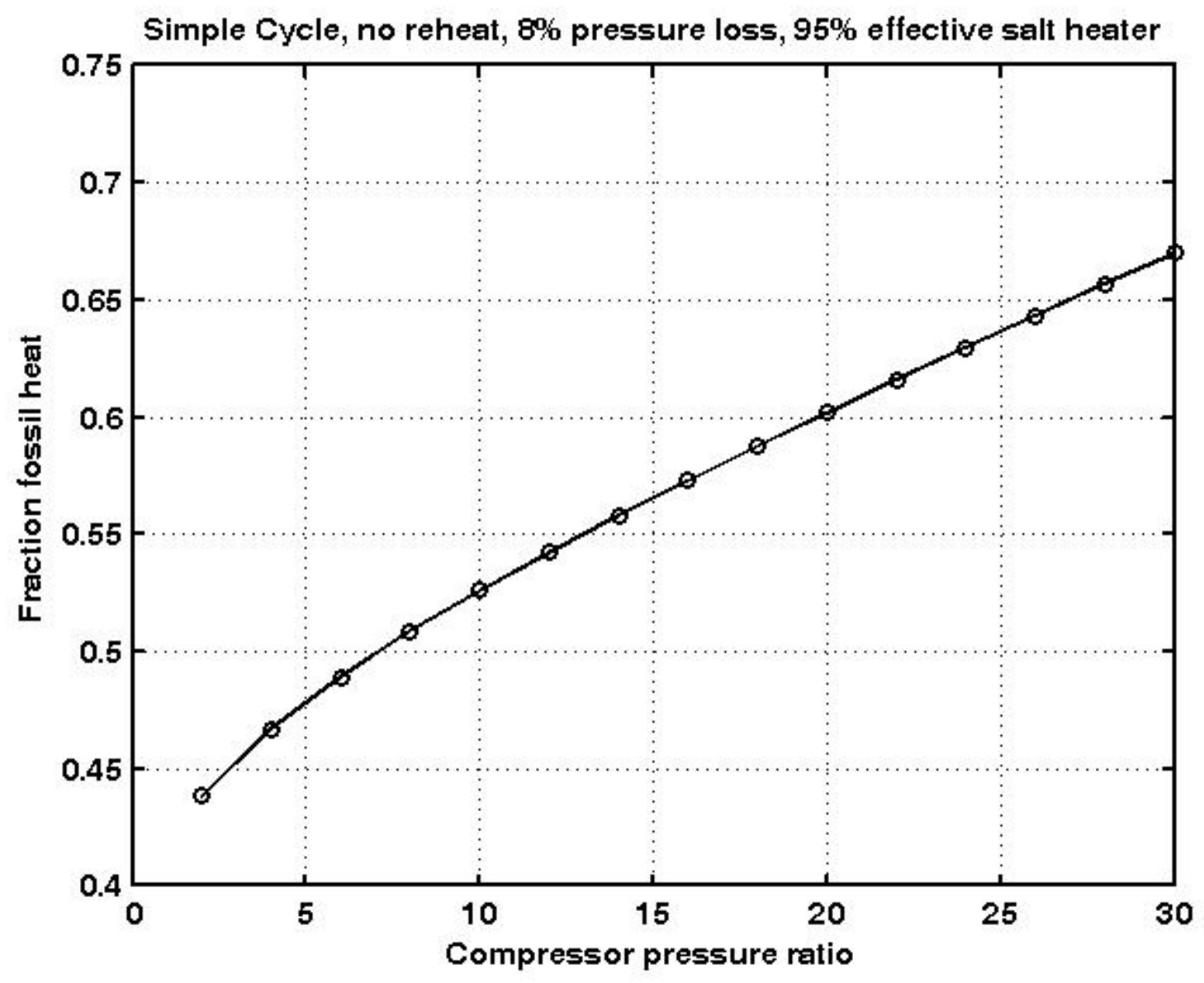

Fig. 4. Fractional burner heat to compressed air.

A significant parameter is the thermal efficiency, simply calculated here as the net shaft power $\left(W_{\text {turbine }}-\right.$ $\left.W_{\text {compressor }}\right)$ divided by the total heat transferred from the AHTR heat exchanger and combustor. Another important parameter is the specific power, defined as net shaft power divided by the product of the working fluid heat capacity rate and the compressor inlet temperature $\left(m C_{p} T_{\text {inlet }}\right)$. Figure 2 shows the thermal efficiency as a function of the specific power for the given cycle parameters for various compressor pressure ratios. The calculations were initiated at a pressure ratio of 2 , and the plotted points are in increments of 2 up to a pressure ratio of 30.

For the case of reactor heat only, the pressure ratio for maximum power is 8 and for maximum efficiency is 12 . When additional heat from the burner is added, the maximum power pressure ratio increases to 16 , and the maximum efficiency occurs at a pressure ratio $>30$. Figure 2 also shows the profound effect of turbine inlet temperature on the efficiency and specific power, but it also shows the noticeable effect of pressure ratio. For the postulated use of this combined cycle machine, these results are promising because the pressure ratio yielding the maximum efficiency when operating under reactor heat (base-load) also yields a maximal amount of power when burner heat is added (peak-load). Also, some of the existing designs of combined-cycle gas-turbine power plants currently operating on the grid have compressor pressure ratios of $\sim 15$. $^{13}$ 
An important result for the combined cycle is the gas-turbine exhaust temperature, which is the inlet temperature to the HRSG of the bottoming Rankine steam cycle. In Fig. 3, this temperature is plotted as a function of compressor pressure ratio for the two cases of unfired (base-load) and fired (peak load) heat addition.

Note that the gas-turbine exit temperature from reactor heat only (base-load) operating at the pressure ratio from Fig. 2 for maximum thermal efficiency is $600 \mathrm{~K}\left(327^{\circ} \mathrm{C}\right)$. This temperature is similar to steam temperatures from light-water reactors but is low compared with peak steam temperatures from fossil power plants. At these temperatures, the steam pressure would be limited in the steam generator to 12.3 $\mathrm{MPa}$. The gas-turbine exit temperature for the fired (peak-load) case at the pressure ratio from Fig. 2 for maximal power would be $\sim 825 \mathrm{~K}\left(552^{\circ} \mathrm{C}\right)$, which would increase the allowable pressure in the steam generator for additional Rankine cycle power. The effect of this exit temperature on the power generated by the steam Rankine portion is presented in the following section.

Another result of interest for the combined cycle is the fractional amount of the total heat transferred to the compressed air by the combustor during operation, as shown in Fig. 4. For the maximum efficiency pressure ratio of $12,54 \%$ of the total heat is provided by the burner, and $57 \%$ for the maximal power pressure ratio of 16 . This increasing fraction is due simply to the increase in compressor exit temperature as the pressure ratio increases since the unfired temperature remains limited by the salt-to-air heat exchanger.

\subsection{STEAM-TURBINE CYCLE MODEL}

The steam-turbine-cycle portion of the proposed combined cycle has two interrelated subsystems: the HRSG and the steam turbine. In modeling the HRSG, the simplest configuration to use was that of a simple heat balance of the gas side and the water side. The gas-turbine outlet conditions of mass flow and temperature specify the HRSG gas-side mass flow and inlet temperature. To complete the gas side of the HRSG, a stack temperature of $120^{\circ} \mathrm{C}$ was specified in order to exhaust the water content as a vapor and avoid "wet stacking." Air ambient temperature was also specified as a parameter as the gas-turbine inlet conditions. The corresponding inlet and outlet temperatures of the water side were specified as approach temperature differences of the gas-side temperatures.

The HRSG outlet temperature and flow are set equal to the steam-turbine inlet temperature and flow. The shaft power extracted by the steam turbine is simply the product of the steam mass flow, the isentropic enthalpy change from the inlet conditions to the condenser conditions, and the adiabatic efficiency of the turbine.

For simplicity, only one pressure level was modeled in the HRSG where only the approach temperatures were specified. One important parameter of steam generator design is the "pinch-point," or closest approach between the hot-gas temperature process line and the water-steam temperature process line. The value of the pinch-point minimum temperature difference was monitored to ensure physically realistic values. The steam-turbine model was also as simple as possible, where only the exit steam quality need be specified. In addition, no regenerative feedwater heaters (i.e., no steam extraction during expansion) were modeled. Because of this simplistic approximation of no feedwater heating, the efficiencies calculated will be lower than those resulting from the more common and realistic feedwater-heater regeneration train configuration. This very simple model should be improved in the future, as this study is just a first step in a feasibility analysis of the concept. 
During these parameter studies, various seemingly physically realistic HRSG approach temperatures and turbine exit qualities resulted in pinch-points approaching zero, which would result in a very large HRSG. Indeed, some parameters resulted in physically unrealistic negative pinch-point temperature differences. This close-approach pinch-point is definitely a problem in combined-cycle HRSG design because usually a high evaporating pressure is desired to increase the power of the turbine. This high evaporating pressure with its concomitant high evaporating temperature, however, results in a small pinch-point which requires a large heat transfer area with resulting high manufacturing costs. This pinch-point was monitored during parameter variations, as well as the effectiveness of the HRSG. If either were physically unrealistic, a cycle parameter was changed until these were reasonable.

Another parameter of importance is HRSG effectiveness, defined as the actual heat transfer divided by the theoretically maximum heat transfer. An effectiveness of unity represents a heat exchanger of infinite extent, so this effectiveness must be less than 1 for physically realistic heat exchangers. One simplistic modeling assumption was that the HRSG approach temperatures used in computing the HRSG effectiveness were specified for both the AHTR (base load) and fossil (peak load) operating conditions. An improved modeling assumption would be to specify the physical (and heat transfer) size of the HRSG and then analyze the heat transfer process in order to compute the actual approach and pinch-point temperatures for all power levels. However, for the purposes of this study, the simplistic assumption of specified approach temperatures was appropriate.

The thermophysical properties of water were computed by the algorithms of the IFC1997 formulation, and the air and combustion gas properties were computed by those of Collona and Silva. ${ }^{14}$

\subsection{BASE-LOAD AND PEAK-LOAD POWER RESULTS}

Initial studies indicate that the gas-turbine conditions will be similar to the existing General Electric model MS7001FA gas turbine in terms of gas pressure ratios and peak temperatures. ${ }^{13}$ The operating points for base-load electricity production are near the peak-efficiency operating conditions for the gas turbine at the lower inlet temperatures, whereas the operating points for peak power production are near the maximum-power-output condition for the gas turbine at the higher inlet temperatures. A combinedcycle system was simplistically modeled with a single gas turbine having the same pressure ratio and gas flow rates as the GE turbine and a steam cycle representative of the commercial GE combined-cycle machine.

The calculations showed a base-load power output (both gas and steam turbine) of 68.0 MW(e) and a peak-load power output of $276.1 \mathrm{MW}(\mathrm{e})$. For base-load operations, the reactor provides $175 \mathrm{MW}(\mathrm{t})$ at $800^{\circ} \mathrm{C}$. For peak power production, the fossil fuel provides an additional $323 \mathrm{MW}(\mathrm{t})$ at a peak gasturbine inlet temperature of $1300^{\circ} \mathrm{C}$.

The free parameters chosen are listed in Table 1. As shown in Table 2, the computed performance using these parameters was reasonable and typical of the currently existing fossil-fuel combined cycle machines. ${ }^{13}$ Regarding Table 1, note that the computational model used here is simple (e.g., no feedwater heaters). Based on this comparison, this simple model yields sufficiently accurate values for the purposes of these scoping studies.

During these computations, the pinch-point temperature difference was very sensitive to the specified turbine exit quality. When quality values of $90 \%$ and $95 \%$ were tried, close or negative pinch-point temperature differences were calculated, the results of which were of course discarded. The increased evaporator pressure resulting from this wet turbine exhaust, which is desirable, unfortunately set up the undesirable low or negative pinch point. This pinch-point problem is, and has always been, a concern in HRSG and steam turbine design. 
Table 1. Parameter listing

\begin{tabular}{|l|c|c|}
\hline \multicolumn{1}{|c|}{ Parameter } & $\begin{array}{c}\text { Peaking } \\
\text { (nuclear + fossil) }\end{array}$ & $\begin{array}{c}\text { Base } \\
\text { (nuclear only) }\end{array}$ \\
\hline Gas-turbine compressor polytropic efficiency, $\%$ & 85 & 85 \\
\hline Gas-turbine turbine polytropic efficiency, $\%$ & 90 & 90 \\
\hline Steam-turbine adiabatic efficiency, $\%$ & 90 & 90 \\
\hline Steam-turbine exit quality, $\%$ & 100 & 90 \\
\hline Ambient temperature, ${ }^{\circ} \mathrm{C}$ & 10 & 10 \\
\hline Condenser approach temperature diff., ${ }^{\circ} \mathrm{C}$ & 10 & 10 \\
\hline HRSG hot-side approach temperature diff., ${ }^{\circ} \mathrm{C}$ & 30 & 30 \\
\hline Gas-turbine inlet temperature, ${ }^{\circ} \mathrm{C}$ & 1300 & 780 \\
\hline Gas-turbine air mass flow rate, $\mathrm{kg} / \mathrm{s}$ & 445 & 445 \\
\hline Compressor pressure ratio & 16 & 16 \\
\hline Gas-turbine pressure loss, $\%$ & 8 & 8 \\
\hline
\end{tabular}

Table 2. Calculated results and comparison

\begin{tabular}{|c|c|c|}
\hline Parameter & $\begin{array}{c}\text { Peaking } \\
\text { (nuclear + fossil) }\end{array}$ & $\begin{array}{c}\text { Base } \\
\text { (nuclear only) }\end{array}$ \\
\hline HRSG effectiveness, $\%$ & 85 & 62 \\
\hline HRSG pinch-point, ${ }^{\circ} \mathrm{C}$ & 25 & 16 \\
\hline HRSG evaporating pressure, $\mathrm{MPa}$ & 1.5 & 0.27 \\
\hline Compressor exit temperature, ${ }^{\circ} \mathrm{C}$ & 426.5 & 426.5 \\
\hline Gas-turbine inlet temperature, ${ }^{\circ} \mathrm{C}$ & 1300 & 781.5 \\
\hline Gas-turbine outlet temperature, ${ }^{\circ} \mathrm{C}$ & 626 & 283 \\
\hline Gas-turbine power, MW & 188.5 & 50.2 \\
\hline Steam-turbine inlet temperature, ${ }^{\circ} \mathrm{C}$ & 596 & 253 \\
\hline Steam-turbine outlet temperature, ${ }^{\circ} \mathrm{C}$ & 20 & 20 \\
\hline Steam-turbine power, MW & 83.6 & 17.8 \\
\hline Total power, MW & 272.1 & 68.0 \\
\hline Gas-turbine thermal efficiency, $\%$ & 37.9 & 28.8 \\
\hline Steam-turbine thermal efficiency, $\%$ & 29.0 & 14.3 \\
\hline Total thermal efficiency, $\%$ & 54.7 & 39 \\
\hline
\end{tabular}


Another parameter of importance identified during the model evaluations was the moisture content of the exhaust. Because the compared gas turbine ${ }^{13}$ used methane as the fossil fuel, the exhaust would have contained moisture as a result of combustion. For the lean conditions postulated here, this moisture represented $\sim 10 \%$ of the exhaust gases. This moisture content added power from the gas turbine by increasing the specific heat by $20 \%$. This increased gas-flow capacity rate also advantageously increased the pinch-point temperature difference in the HRSG. During postulated operation with heat only from the AHTR, the gas-turbine power will decrease and the pinch-point will decrease when this combustion moisture is not present.

\subsection{ALTERNATIVE POWER CYCLES}

Future studies will examine alternative combined cycles. A wide variety of system configurations exist to boost base-load to peak-load power levels, boost efficiency, or increase the nuclear heat fraction when the plant is operating in a peak-power production mode. However, these configurations have not yet been analyzed. Two interconnected factors will determine the optimum combined cycle. Electric grid characteristics will partly determine the desired relative output of base-load versus peak-load power. The power-plant capital cost will also influence design. The nuclear plant has high capital costs and thus will operate at base-load conditions. Consequently, the economic trade-offs in the power cycle during baseload operation will be optimized for capacity factors near $90 \%$. In contrast, the economic trade-offs in the power-cycle design during peak-load operation are optimized based on operating 10 to $50 \%$ of the time. The economic optimum design for peak power production will likely be at somewhat lower peak efficiency in exchange for lower initial capital costs.

Examples of alternative configurations include (1) steam injection into the gas turbine after air compression but before nuclear heating (increased base-load versus peak power production), (2) heating HRSG steam using nuclear heat to temperatures found in advanced steam plants (increased nuclear baseload efficiency and output), or (3) inter-stage cooling in the air compressor (increased capital cost for increased efficiency under base-load conditions). 


\section{MARKETS}

The capital and operating costs of different power generation technologies determine in which markets particular technologies are competitive. The NCCC plant has an unusual cost structure. The nuclear base-load component of the plant will have high capital costs but low operating costs similar to those of other nuclear plants. The peak-load component of the plant is a modified combined-cycle plant with low capital costs per $\mathrm{kW}(\mathrm{e})$ of capacity-similar to traditional natural-gas combined-cycle plants that have estimated costs of $\sim \$ 570 / \mathrm{kW}(\mathrm{e})$-h. However, the operating costs will be much lower than those of traditional natural-gas-fired combined-cycle plants. Some of the heat is low-cost nuclear heat, and some of the heat is at a higher cost (natural gas, jet fuel, or hydrogen). The other unique characteristic is the ability to alter power output very rapidly, far more rapidly than any fossil-electric generating technology. This creates a unique set of markets for NCCC plants.

\subsection{PREMIUM MARKETS}

For a combined-cycle plant with electricity sold to the electrical grid, three premium electric markets ${ }^{15}$ exist in which the value and price of electricity far exceed the price of base-load electricity (Table 3 ).

Table 3. Premium power-grid electrical markets in the United States ${ }^{15}$

\begin{tabular}{|c|c|c|c|}
\hline $\begin{array}{c}\text { Technology } \\
\text { parameter }\end{array}$ & Regulation & $\begin{array}{c}\text { Spinning } \\
\text { reserve }\end{array}$ & Load shifting and load leveling \\
\hline $\begin{array}{c}\text { Capital cost, } \\
\$ / \mathrm{kW}\end{array}$ & 700 & $300-1000$ & $\begin{array}{c}300 \text { (load leveling) } \\
400-1000 \text { (peak shaving and load } \\
\text { shifting) } \\
\text { (renewables) }\end{array}$ \\
\hline $\begin{array}{c}\text { Total market potential, } \\
\text { GW }\end{array}$ & $30-40$ & $70-100$ & 80 (cost sensitive) \\
\hline System power level & Up to $200 \mathrm{MW}$ & $\begin{array}{c}10 \mathrm{MW} \text { to } \\
1 \mathrm{GW}\end{array}$ & $1 \mathrm{MW}$ to $1 \mathrm{GW}$ \\
\hline $\begin{array}{c}\text { Discharge time at rated } \\
\text { power }\end{array}$ & $\begin{array}{c}\text { Seconds to } \\
\text { minutes }\end{array}$ & 0.2 to $2 \mathrm{~h}$ & 1 to $8 \mathrm{~h}$ \\
\hline Lifetime, years & 20 & 40 & $7-10$ \\
\hline
\end{tabular}

\subsubsection{Regulation}

Electric consumers turn equipment on and off with switches that operate in a fraction of a second. Electric generators can vary the power output over a period of minutes. If the demand and generation do not match, the system frequency and voltage change. If the changes are too great, however, both customer and utility equipment is damaged. Ultimately, the system can fail, with a resultant blackout. The electrical system works because the electric grid averages demand over many customers so that the generators do not experience rapid changes in power demand. As a consequence, the larger electrical grids are more stable, have higher-quality electricity (proper voltage and frequency), and are more reliable than smaller electrical grids. 
Because the stability of many electrical grids is decreasing, better methods are needed to ensure grid regulation and delivery of high-quality electricity. This situation is partly a consequence of the growing electric demand associated with electronics. With traditional electrical loads, such as incandescent light bulbs, if the line voltage drops (insufficient power generation), both the electrical current and the power demand drop. This provides time for the electrical generators to speed up or slow down as required to match power production with power demand. However, with many electronic devices, as the voltage drops, the device demands more current, and the power demand goes up. Hence, the system provides less time for electrical generators to respond to the demand. The system becomes more prone to failure, and the quality of electricity decreases.

Figure 5 shows the variations in demand for 1 day on the Texas utility grid and the rapid variations in power demand over $1 \mathrm{~h} .{ }^{16}$ This figure shows the rapid change in electrical demand that can occur, partly caused by changing electrical load and partly by the changing frequency and voltages on the grid. There are strong incentives to reduce these short-term variations by better grid regulation.

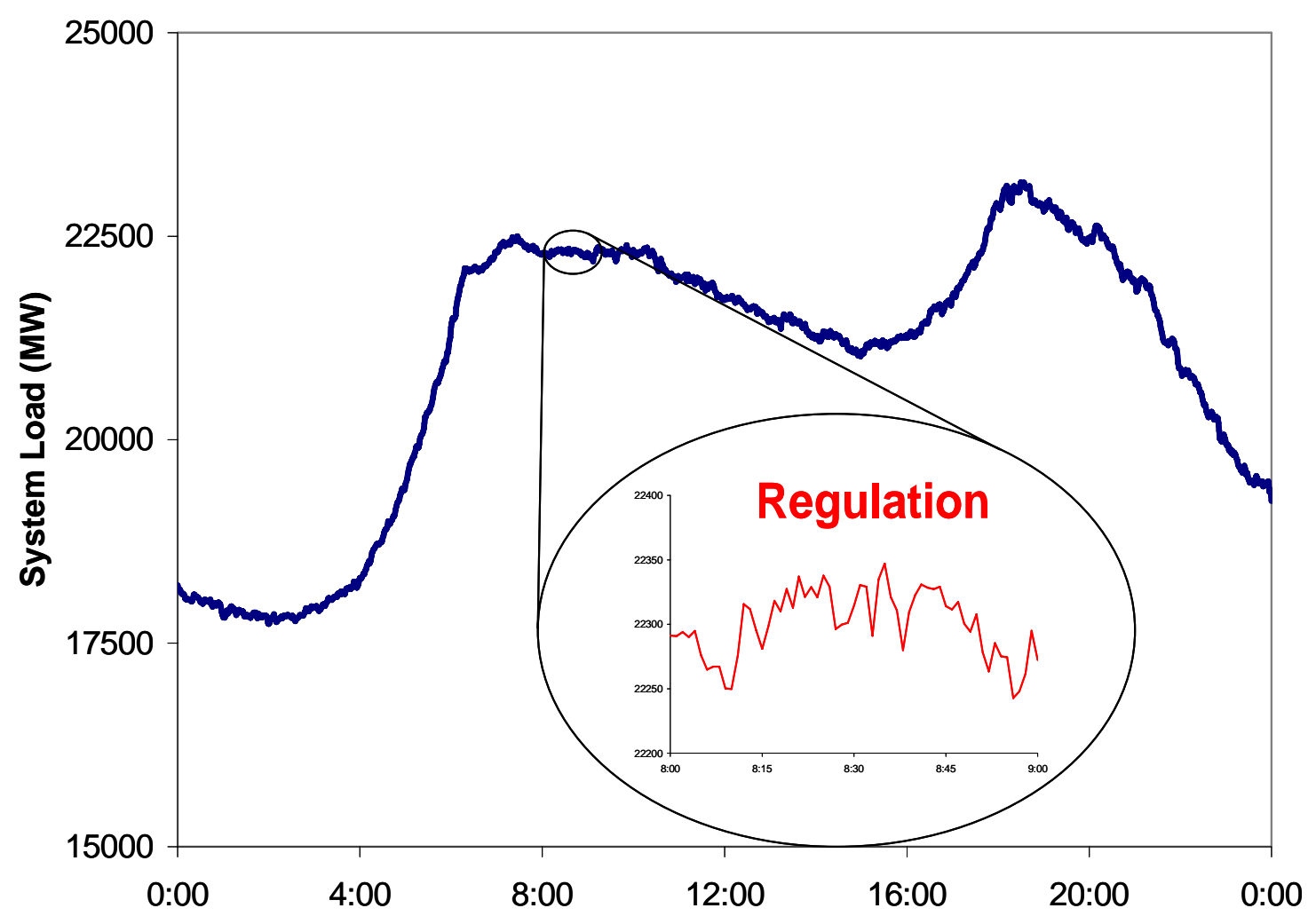

Fig. 5. A typical electric-power demand load on the ERCOT (Electric Reliability Council of Texas) electric grid over a $24-\mathrm{h}$ period on a winter day. ${ }^{16}$

Because of its rapid response time, a NCCC plant can potentially be used to provide electricity for this variable electrical demand and thus produce higher-quality electricity (constant voltage and frequency) and provide the time for other power generation units to increase or decrease their electrical output. The time period varies from seconds to tens of minutes, depending upon the electrical grid size as well as other factors. In small grids where there are fewer customers and less load averaging, the demands for power regulation are more severe. In this mode of operation, the NCCC plant would operate 
continuously at some power level (hot and spinning) with the power levels varied as needed. The allowable capital cost for this capability (Table 3) significantly exceeds the incremental peakingcapability costs for a NCCC plant.

\subsubsection{Reserve Power (Spinning Reserve)}

Reserve power provides generating capacity in the event that an electrical generator goes off-line for unexpected reasons. Presently such a situation is handled by putting online additional power plants that run at partial load with the capability to produce more power if another unit goes off-line. However, this process represents expensive backup power. An NCCC plant could potentially provide spinning reserve by operating at low power levels with the capability to rapidly go to peak power. For this application, high power output must be provided for periods of time ranging from tens of minutes to a few hours-the time required to startup another power generation system. The allowable capital cost significantly exceeds the incremental spinning-reserve capability cost for a NCCC plant.

\subsubsection{Load Shifting and Load Leveling}

The demand for electricity varies by the time of day, the week, and the season. The cost and price of electricity are high at times of peak power demand and low at times of low power demand. The high cost of peak power reflects the fact that the facilities needed to produce much of this power are operated for only a few hundred or a thousand hours per year, as shown in Table 4, which lists the marginal prices of electricity in 2004 for nine U.S. electric grids. ${ }^{17}$ The table shows the number of hours per year that electricity could be bought or sold for a particular price range in dollars per megawatt (electrical)-hour. The prices of electricity for a few hours per year can be much higher. For example, the Texas grid (ERCOT) has had spot market prices as high as \$1500 MW(e)-h.

Large differences in the cost of electricity versus time occur across the country, and significant quantities of electricity are sold at high wholesale prices in such grids as ISO-New England, Florida Power and Light, and the PJM (Pennsylvania, New Jersey, and Maryland). In any of these markets, an NCCC plant has the potential to provide lower-cost peak power.

In a number of markets, an NCCC plant using electrolysis for hydrogen production could be potentially competitive when low-cost electricity is used to produce hydrogen and the electricity is sold during periods of high electricity costs. Generally, the price of electricity at peak times must be several times that of input electricity for breakeven economics to occur because of the round-trip efficiency of electricity to hydrogen and back to electricity. The fact that different markets have different characteristics must also be considered. For example, electric prices for the Los Angeles Department of Water and Power show low-priced electricity [\$10-15/MW(e)-h] for almost 1500-h per year but highpriced electricity (over three times higher) for over 5000 thousand hours a year. This double-hump price curve reflects the low nighttime demand and the high daytime demand for electricity in Los Angeles. If an NCCC plant with hydrogen production was used in this system, the required hydrogen storage volumes would be equal to that needed to cover day-night shifts and weekday-weekend shifts in electric demand. The electric prices for Seattle Power and Light show a similar double-hump curve, but the situation is much different. The utilities in the Pacific Northwest have large quantities of hydroelectric power that make it inexpensive to meet the variable daily demand for electricity. However, the utilities have excess electricity in the spring, when water from the snow pack is dumped over the dams or through the generators to produce electricity. In contrast, in late fall the hydroelectric power production is low because the snow pack has melted and water flows have decreased. Fossil units with high operating costs are used to meet the power demand during this time of year. If an NCCC plant were used in these systems, the hydrogen storage volumes would be seasonal, reflecting the seasonal characteristics of power costs in the Northwest. 
Table 4. 2004 Electricity prices ${ }^{17}$ versus the number of hours for different electrical grids

\begin{tabular}{|c|c|c|c|c|c|c|c|c|c|}
\hline & \multicolumn{9}{|c|}{ Hours per year } \\
\hline $\begin{array}{c}\text { \$ per } \\
\text { MW(e)-h } \\
\end{array}$ & Seattle & $\begin{array}{l}\text { ISO New } \\
\text { England }\end{array}$ & Southern & \begin{tabular}{|c|}
$\begin{array}{c}\text { Arizona } \\
\text { PS }\end{array}$ \\
\end{tabular} & $\begin{array}{c}\text { Florida } \\
\text { P\&L } \\
\end{array}$ & AEP & LADWP & $\begin{array}{c}\text { Com. } \\
\text { Edison }\end{array}$ & PJM \\
\hline$<5$ & - & 69 & - & 7 & - & 19 & 3 & 406 & 106 \\
\hline 5-10 & 170 & 9 & - & - & - & 32 & 9 & 229 & 59 \\
\hline 10-15 & 513 & 11 & - & 4776 & 50 & 3155 & 1470 & 1105 & 141 \\
\hline 15-20 & 1866 & 31 & 238 & 700 & 425 & 3014 & 67 & 2734 & 479 \\
\hline 20-25 & 1111 & 157 & 887 & 65 & 83 & 1112 & 88 & 981 & 761 \\
\hline 25-30 & 522 & 260 & 1342 & 126 & 89 & 360 & 374 & 694 & 1060 \\
\hline $30-35$ & 1619 & 391 & 1902 & 560 & 916 & 307 & 489 & 863 & 1067 \\
\hline $35-40$ & 981 & 797 & 1658 & 614 & 1645 & 271 & 386 & 438 & 1093 \\
\hline $40-45$ & 627 & 1256 & 1826 & 588 & 1641 & 175 & 657 & 311 & 819 \\
\hline $45-50$ & 508 & 1479 & 378 & 462 & 1343 & 97 & 1506 & 273 & 691 \\
\hline 50-55 & 341 & 1314 & 83 & 358 & 1166 & 67 & 1859 & 181 & 531 \\
\hline $55-60$ & 309 & 1028 & 87 & 268 & 671 & 41 & 1089 & 163 & 449 \\
\hline 60-65 & 147 & 651 & 88 & 186 & 399 & 25 & 516 & 109 & 358 \\
\hline 65-70 & 25 & 429 & 96 & 53 & 159 & 21 & 165 & 86 & 275 \\
\hline 70-75 & 30 & 285 & 86 & 15 & 77 & 21 & 66 & 69 & 224 \\
\hline 75-80 & 15 & 186 & 45 & 2 & 59 & 11 & 3 & 45 & 176 \\
\hline 80-85 & - & 107 & 33 & 1 & 20 & 11 & 17 & 32 & 145 \\
\hline 85-90 & - & 82 & 13 & 1 & 15 & 9 & 15 & 22 & 103 \\
\hline 90-95 & - & 61 & 18 & - & 6 & 11 & 5 & 13 & 72 \\
\hline$>95$ & - & 181 & 4 & 2 & 20 & 25 & - & 30 & 175 \\
\hline $\begin{array}{l}\text { Total } \\
\text { Hours }\end{array}$ & 8784 & 8784 & 8784 & 8784 & 8784 & 8784 & 8784 & 8784 & 8784 \\
\hline
\end{tabular}




\subsection{SMALL-GRID MARKETS (INCLUDING DEVELOPING COUNTRIES)}

Small electrical grids, such as those in developing countries, present difficult operating and economic challenges. Large electrical grids create an electrical demand that is averaged over millions of customers. A single customer turning equipment off or on has little impact on the total electrical demand. Similarly, a single power plant only produces a small fraction of the electric generation and thus would have a limited impact on the electrical grid if it were to shut down. A large grid as measured in customers and power generation units implies slow changes after a major customer shuts down or a single generator goes off line. The changes in voltage are small and high-quality electric power can be delivered. Equally important, the large number of different generating units allows careful dispatch of the lowest cost units to provide electricity.

In contrast, in a small grid the changes in the demand for electricity of just a few large customers have large impacts on the total demand for power and power quality (voltage, phase, and frequency). Similarly, the loss of a single generating unit can cause large grid disturbances because that unit represents a significant fraction of the total electricity-generating capacity. For the same level of equipment reliability and operator skills, a small grid will have more blackouts, lower-quality power (voltage variations), and higher costs. To achieve the same levels of reliability and power quality, much higher spinning reserve capability is required as a fraction of the generating capacity of the grid.

The need to accommodate variable load and provide more spinning reserve to ensure grid stability implies that a nuclear plant in a small electrical gird will likely operate at variable load. However, the economics of traditional base-load nuclear plants are poor if these plants must operate at variable load to meet grid requirements. In addition, it is difficult to integrate a base-load nuclear power plant into a small grid unless the grid already has a large hydroelectric component

For small electrical grids, such as those in developing countries, an NCCC plant may be the enabling technology for use of nuclear energy by providing base-load electric power, peak-load electric power, and a method to stabilize the electric grid to produce high-quality electric power. The unique rapid-response capability provides a method for stabilizing the grid when a major customer comes on line or another generating unit goes off line for any reason. The peaking capability can provide a low-cost reserve margin for the grid. It may also be the enabling technology that will allow small grids to produce the same high-quality power found in large electrical grids.

\subsection{GREENHOUSE IMPACTS}

Concerns about climate change may result in constraints on the releases of greenhouse gases to the atmosphere. Major programs are under way to develop methods to sequester carbon dioxide in geological structures. Recent assessments ${ }^{18}$ indicate that sequestration may increase bus-bar electrical costs by up to $40 \%$ for base-load power production systems. However, the costs for carbon dioxide sequestration for fossil-fired peak power units will be much higher. These units operate only a limited number of hours per year; thus, the capital cost component of the cost of electricity is much greater per kW(e)-h. Consequently, any restrictions on greenhouse gas releases would significantly improve the relative competitive advantage of an NCCC plant that produces and uses hydrogen. 


\section{REACTOR AND INTERMEDIATE HEAT-TRANSPORT LOOP OPTIONS}

\subsection{REACTOR OPTIONS}

The NCCC requires a high-temperature reactor so the compressed air, after nuclear preheating, is above the auto-ignition temperature of the fuel. This implies, after accounting for temperature drops across intermediate heat-transport loops, peak temperatures of $\sim 700^{\circ} \mathrm{C}$ for the reactor. Several different hightemperature reactors can potentially be coupled to this power cycle.

- Molten Salt Reactors (MSRs). MSRs are liquid fuel reactors that were originally developed for the Aircraft Nuclear Propulsion program of the 1950s and were to be coupled to jet engines. Two small test reactors were built. Since that program, there have been major developments in Brayton power systems but only limited development of MSRs. The MSR is a longer-term reactor option for an NCCC plant.

- High-Temperature Gas-Cooled Reactors (HTGRs). HTGRs are helium-cooled reactors that use solid coated-particle fuels. Several HTGRs have been built, and several programs are underway to commercialize this reactor, ${ }^{5}$ including the Next-Generation Nuclear Plant program of the U.S. Department of Energy. The HTGR is a realistic candidate for an NCCC plant.

- Advanced High-Temperature Reactor (AHTR). The studies herein coupled the NCCC plant to an AHTR. The AHTR is a proposed liquid-salt-cooled high-temperature reactor ${ }^{4}$ that uses the same coated-particle fuels as are used in helium-cooled high-temperature reactors and is currently under development. Because the AHTR is a liquid-salt-cooled reactor, its characteristics as seen by the NCCC plant appear identical to those of a MSR - the reactor originally developed for the nuclear jet engine. (The fundamental difference between the MSR and the AHTR is that the MSR dissolves the fuel in the salt coolant whereas the AHTR uses a solid fuel and a clean salt coolant.)

\subsection{INTERMEDIATE HEAT-TRANSPORT LOOP}

Heat must be transported from the high-temperature reactor to the combined-cycle plant using an intermediate heat-transport loop. The intermediate heat transport loop isolates the reactor coolant from the air Brayton power cycle to assure fission products are not transported from the reactor to the environment. At high temperatures, this includes preventing migration of tritium from the reactor to the environment. The intermediate loop also isolates the NCCC plant from the reactor. It assures that fires or other accidents with fossil fuels or hydrogen can not impact nuclear plant safety. It also allows the power generation equipment to be outside the high-security envelope of the reactor. This has significant cost benefits.

There are several candidate fluids [5] for the intermediate heat-transport loop: inert gases including helium, noble gas mixtures, and helium nitrogen mixtures, liquid metals such as sodium and potassium, and liquid salts. Multiple experiments and engineering studies are underway in the United States and elsewhere on the coupling of high-temperature reactors to hydrogen production plants and other chemical plants. The requirements for heat transport from a high-temperature reactor to a hydrogen plant are somewhat similar to heat transport from a high-temperature reactor to an NCCC plant. Consequently, those studies will provide much of the basis for the engineering studies to choose the optimum heat transport fluid for this specific application. 


\section{TECHNOLOGY CHALLENGES}

Most of the component technologies for a NCCC power system exist in commercial form. Hightemperature reactors have been developed and built, but they are not yet a commercial technology. In terms of the power cycle, there are several significant remaining challenges.

- System structure. There are multiple possible NCCC power system configurations. System studies are required to determine which configurations will be preferred.

- Nuclear heat exchanger. The heat-transport loop between the reactor and the NCCC power cycle must be developed. This includes comparison and selection of the best heat-transfer fluid for this application.

- Integrated design. Designs for an integrated NCCC power system must be developed and tested. However, there is one major challenge to creating these designs that will require significant work. Since their development in the 1930s, gas turbines have been designed with the constraint of matching the air-to-fuel ratio to ensure flame stability and complete combustion. In a NCCC system, this constraint is removed. The air compressor in an NCCC system is powered by nuclear heat only, and this, in principle, allows for very rapid increases in turbine power levels relative to traditional gas turbines. In such a system, there is no need to speed up the compressor and the fuel is injected into hot air above its auto-ignition temperature. However, this is a design space where there has been little analysis and no significant testing.

- Hydrogen fuel options. The option of hydrogen fuel is only partly understood. Significant system studies are required. Work is under way to develop all of the required technologies as part of various hydrogen initiatives worldwide. 


\section{CONCLUSIONS}

The NCCC power plant is a new concept in power plant design that combines advantages of nuclear power plants and traditional fossil-fired combined-cycle plants. A first-level analysis of the concept has been completed that indicates technical viability and potential economic competitiveness in specific markets. Such a power system reactor has multiple potential advantages.

1. Premium electric markets. The rapid response capabilities of this system may allow nuclear energy to enter the premium-price electricity markets for grid regulation, spinning reserve, and load following. Perhaps of greater, but not fully defined importance, the very rapid response to electric demand creates new capability that was not previously available for ensuring high-quality electricity on the grid. The use and value of this potentially new capability is not yet fully understood.

2. Small reactors for small electrical grids. The developing world has small electrical grids with highly variable electrical loads. There is a need for reactors that are economic and can load follow. The capability to rapidly respond to changes in power demand may allow this system to be used for spinning reserve, frequency control, and voltage control - major operational problems in small electrical grids with a small number of generating units. It also may improve grid reliability by providing a system that can rapidly respond to loss of other electrical generating units (spinning reserve). As a secondary benefit, the NCCC power cycle is a derivative of traditional natural-gas combined-cycle plants that are used in many developing countries - a power cycle these utilities are familiar with.

3. Reduced carbon dioxide emissions. Fossil fuels are universally used to provide peak electrical power because (1) they are storable and (2) the cost of equipment to convert the fuel to electricity is low relative to the cost of the fuel. A long-term constraint is the release of greenhouse gases. For peak power production, the nuclear heat preheats the air approximately halfway to its peak temperature and thus can reduce by up to a factor of 2 the use of fossil energy for peak electrical production. If hydrogen replaces the natural gas or jet fuel, an NCCC system can provide peak electricity without the production of greenhouse gases.

4. Improved economics. The system has the potential for improved economics by combining low-cost base-load nuclear heat production that allows full utilization of the nuclear heat source with peak power production using low-capital-cost combined-cycle systems.

5. Available technology. Most of the power conversion technology is existing technology that can be coupled to high-temperature reactors. Thus, the development of high-temperature reactors is not coupled to development of new power conversion systems - except for the nuclear heat exchanger.

6. Higher efficiency. Gas turbines, with technologies such as actively cooled hollow blades, can operate at much higher temperatures than nuclear reactors. The NCCC system allows operations to be conducted at higher temperatures and thus higher efficiencies than nuclear-only systems.

A significant amount of additional work will be required to understand both the advantages and disadvantages of this technical concept. There are significant technical uncertainties. The NCCC does require a high-temperature reactor so the compressed air after nuclear preheating is above the autoignition temperature of the fuel. Several different high-temperature reactors can potentially be coupled to this power cycle. 


\section{REFERENCES}

1. Anderson, J., C. Conklin, and C. W. Forsberg, "Base-Load and Peak Electricity from a Combined Nuclear Heat and Fossil Combined-Cycle Power Plant," Proceedings of Global 2007: Advanced Nuclear Fuel Cycles and Systems, Boise, Idaho, September 9-13, 2007, American Nuclear Society, La Grange Park, Illinois, 2007.

2. C. W. Forsberg, "Economics of Meeting Peak Electric Demand Using Nuclear Hydrogen and Oxygen," Proc. of the International Topical Meeting on the Safety and Technology of Nuclear Hydrogen Production, Control, and Management, Boston, Massachusetts, June 24-28, 2007, American Nuclear Society, LaGrange Park, Illinois, 2007.

3. D. F. Williams, Assessment of Candidate Molten Salt Coolants for the NGNP/NHI Heat-Transfer Loop, ORNL/TM-2006/69, Oak Ridge National Laboratory, Oak Ridge, Tennessee, June, 2006.

4. D. T. Ingersoll, C. W. Forsberg, and P. E. MacDonald, Trade Studies on the Liquid-Salt-Cooled Very High-Temperature Reactor: Fiscal Year 2006 Progress Report, ORNL/TM-2006/140, Oak Ridge National Laboratory, Oak Ridge, Tennessee, December, 2006.

5. I. Minatsuki and Y. Mizokami, "Evaluation for Reasonableness of Power Conversion System Concepts in the Gas Turbine High-Temperature Reactor (GTHR300)," Proceedings of the International Congress on Advances in Nuclear Power Plants, May 13-18, 2007, Nice Acropolis, France, 2007.

6. A. P. Frass and A. W. Savolainen, Design Report on the Aircraft Reactor Test, ORNL-2095, Oak Ridge National Laboratory, Oak Ridge, Tennessee, 1956.

7. U.S. Department of Energy, Office of Fossil Fuels, "Carbon Sequestration Atlas of the United States and Canada," Washington, D.C., March 2007, http://www1.eere.energy.gov/hydrogenandfuelcells/mypp/pdfs/production.pdf.

8. A. I. Miller and R. B. Duffy, "Meeting the Near-Term Demand for $\mathrm{H}_{2}$ Using Nuclear Electricity in Competitive Power Markets," Proceedings of the Second Information Exchange Meeting on Nuclear Production of Hydrogen, Argonne National Laboratory, October 2-3, 2003, Nuclear Energy Agency, Paris, 2003.

9. U.S. Department of Energy, Hydrogen Program Multi-Year Research, Development, and Demonstration Plan, Washington, D.C., November 14, 2006.

10. Texas Institute for Advancement of Chemical Technology, NP 2010 Texas Gulf Coast Nuclear Feasibility Study: Final Report, prepared for the U.S. Department of Energy, February 28, 2005.

11. C. W. Forsberg, "Economic Implications of Peak vs Base-Load Electricity Costs on Nuclear Hydrogen Systems," CD-ROM, Proceedings of the American Institute of Chemical Engineers 2006 Annual Meeting, San Francisco, California, November 12-17, 2006.

12. D. G. Wilson and T. Korakianitis, Chapter 3 in The Design of High-Efficiency Turbomachinery and Gas Turbines, $2^{\text {nd }}$ edition, Prentice Hall, Upper Saddle River, New Jersey, 1988. 
13. General Electric Gas Turbine and Combined Cycle Products, http://www.gepower.com/prod_serv/products/gas_turbines_cc/en/downloads/gasturbine_cc_produc ts.pdf, accessed June 2007.

14. P. Colonna and P. Silva, "Dense Gas Thermodynamic Properties of Single and Multi-Component Fluids for Fluid Dynamics Simulations,” J. Fluids Engrg.125, 414 (2003).

15. U.S. Department of Energy, Office of Science, Technology and Applied R\&D Needs for Electrical Energy Storage, Resource Document for the Workshop on Basic Research Needs for Electrical Energy Storage, April 2-3, 2007, Washington, D.C., March 2007.

16. Electric Reliability Council of Texas, "1999 FERC 714 Data” (February 2002).

17. U.S. Federal Energy Regulatory Commission, Form 714-Annual Electric Control and Planning Area Report, Washington, D.C., 2004, www.ferc.gov/docs-filing/eforms/form$\underline{714 / \text { data.asp\#skipnavsub }}$

18. Massachusetts Institute of Technology, The Future of Coal: Options for a Carbon-Constrained World, Cambridge, Massachusetts, 2007. 
ORNL-6980

\section{INTERNAL DISTRIBUTION}

1. S. J. Ball (ballsj@ornl.gov)

2. G. L. Bell (bellgl@ornl.gov)

3. B. B. Bevard (bevardbb@ornl.gov)

4. J. L. Binder (binderjl@ornl.gov)

5. E. D. Collins (collinsed@ornl.gov)

6. J. C. Conklin (conklinjc@ornl.gov)

7. W. R. Corwin (corwinwr@ornl.gov)

8. C. W. Forsberg (forsbergew@ornl.gov)

9. E. C. Fox (foxec@ornl.gov)

10. J. B. Green (greenjbjr@ornl.gov)

11. S. R. Greene (greenesr@ornl.gov)
12. R. F. Holdaway (holdawayrf@ornl.gov)

13. D. T. Ingersoll (ingersolldt@ornl.gov)

14. G. T. Mays (maysgt@ornl.gov)

15. G. E. Michaels (michaelsge@ornl.gov)

16. C. V. Parks (parkscv@ornl.gov)

17. J. E. Rushton (rushtonje@ornl.gov)

18. J. J. Simpson (simpsonjj@ornl.gov)

19. P. J. Otaduy (otaduypj@ornl.gov)

20. D. F. Williams (williamsdf2@ornl.gov)

21. Office of Technical Information and Classification (johnsonjm@,ornl.gov)

\section{EXTERNAL DISTRIBUTION}

22. T. L. Cook, U.S. Department of Energy, NE-20, Germantown Bldg, 1000 Independence Ave, SW, Washington, DC 20585 (trevor.cook@hq.doe.gov)

23. M. A. Feltus, U.S. Department of Energy, NE-20, Germantown Bldg, 1000 Independence Ave, SW, Washington, DC 20585-1290 (madeline.feltus@hq.doe.gov)

24. F. J. Goldner, U.S. Department of Energy, NE-20, Germantown Bldg, 1000 Independence Ave, SW, Washington, DC 20585-1290 (frank.goldner@hq.doe.gov)

25. P. Hildebrandt, Idaho National Laboratory, P.O. Box 1625, Idaho Falls, Idaho 83415 (phil.hildebrandt@inl.gov)

26. P. E. MacDonald, 2943 Sonterra Drive, Cedar Hill, Texas 75104 (pemcedarhill@yahoo.com)

27. T. J. O'Connor, U.S. Department of Energy, NE-40, Germantown Bldg, 1000 Independence Ave, SW, Washington, D 20585 (tom.oconnor@nuclear.energy.gov)

28. P. F. Peterson, University of California, Berkeley, Nuclear Engineering Department, 4153 Etcheverry Hall, Berkeley, CA 94720-1730 (peterson@nuc.berkeley.edu)

29. S. R. Sherman, Idaho National Laboratory, P.O. Box 1625, Idaho Falls, Idaho 83415-3865 (steven.sherman@inl.gov)

35. C. J. Sink, Jr., U.S. Department of Energy, NE-20, Germantown Bldg,1000 Independence Ave, SW, Washington, DC 20585 (carl.sink@nuclear.energy.gov)

37. R. M. Versluis, U.S. Department of Energy, NE-20, Germantown Bldg, 1000 Independence Ave, SW, Washington, DC 20585 (rob.versluis@hq.doe.gov) 